\title{
Evaluation of the Online Mode-Based the Candidate of Headmaster Training Program by Using the Kirkpatrick Evaluation Model
}

\author{
Marinu Waruwu ${ }^{1 *}$ (iD \\ Satya Wacana Christian University, Salatiga, Indonesia \\ *Corresponding author: marinu.waruwu@uksw.edu
}

\begin{abstract}
Educational institutions must have creative innovation so that education management continues to run optimally. One of the innovations is the online model-based training of school principal candidates. The objective of this study is to analyze the Effectiveness of the Online Mode-Based Principal Training Program Using the Kirkpatrick Evaluation Model. The training evaluation using the Kirkpatrick model used 4 (four) levels, they were 1) reaction; 2) learning; 3) behavior; 4) results. The research method used was a combination (mixed method). The sample of this research was the training participants of prospective principals, totaling 12 people. Data collection techniques included questionnaires, interviews, observations, and documentation studies. The data analysis technique was carried out by quantitative descriptive and equipped with qualitative analysis based on the results of interviews, observations, and documentation studies. The results show that the success rate of training for prospective principals at all levels is in a good category. The success rate at each level is as follows: 1) evaluation of the participant's reaction level is in the good category level; 2) evaluation of learning level is in good category level; 3) evaluation of behavior level is in good category level; 4) evaluation results are in the good category level, in other words, training has an impact on school development. The results of this study are used as material for evaluating the effectiveness of training for prospective principals and as input for the development of community service programs in the future.
\end{abstract}

Keywords: Evaluation, Training, Reaction, Learning, Behavior, Outcome

$\begin{array}{lll}\text { History: } & \text { Publisher: Undiksha Press } \\ \text { Received : June 15, } 2021 & \text { Licensed: This work is licensed under } \\ \text { Revised : June 20, } 2021 & \text { a Creative Commons Attribution 3.0 License } \\ \text { Accepted : September 23, } 2021 & \text { CC } \\ \text { Published : October 25, } 2021 & \text { ( ) }\end{array}$

\section{INTRODUCTION}

The COVID-19 pandemic had a significant impact on various aspects of life. The impact of Covid 19 affects the economy, health, poverty, and education fields (Choi et al., 2021; Muthuprasad et al., 2021b; Srifuengfung et al., 2021). One of the most significant impacts is on the education sector (Muhyiddin, 2020; Shirish et al., 2021). In the education field, both primary and secondary education as well as higher education, information technology is utilized optimally so that learning continues amid in large-scale social restrictions (Chen \& Li, 2011; Sert \& Boynueğri, 2017; Yavuz et al., 2021). This is the best alternative so that teaching and learning continue and services to students continue to be maximized (Mutohhari et al., 2021; Tuma, 2021). The pandemic situation encourages educational institution managers to switch to distance learning through various online applications such as learning management systems, zoom meetings, google meet, Jitsy, and Whatsapp (Albashtawi \& Al Bataineh, 2020; Guswara, 2020; Mulyono et al., 2021). These various applications facilitate the continuity of the learning process. This online model application is maximized creatively in the management of the world of education (Ramkissoon et al., 2020; Sujarwo et al., 2020). Learning continues even at a distance, this is facilitated by information technology (Supriyanto et al., 2020; Van Nuland et al., 2020). Online teaching requires teachers to solve problems and apply new approaches to learning and teaching (König et al., 2020).

The Master of Education Administration Study Program, Faculty of Teacher Training and Education, Satya Wacana Christian University has collaborated with the Christian 
Education Foundation of Salatiga City to provide prospective school principals in the form of training. The training is carried out in an online mode. Online model training is online distance training that utilizes computer technology, computer networks, multimedia applications, and the internet. The online mode is carried out using the Zoom Meeting application, Google Meet, WhatsApp Group, Email, Google Form, and Google Drive (Dhawan, 2020; Husain et al., 2021). The implementation is in two stages with On the Job Training and In Service Training models. During this Covid-19 pandemic, online training is the main choice to maintain social distancing (Haddock et al., 2020; Selvaraj et al., 2021). Online training has advantages such as communication between participants that can be done anytime and anywhere, the schedule and training materials are structured, the use of time is more efficient and effective, additional information can be accessed easily via the internet, cost-effectiveness, self-study, and global participants (Andel et al., 2020; Lage-Cala et al., 2020).

In addition to the advantages in terms of online facilities, training participants benefit from the training such as receiving material on responsibilities as school principals, knowing the challenges and opportunities for improving school quality, having the ability to apply materials at a technical level, understanding teacher development strategies, learning development strategies, and strategies for evaluating and supervising the school's flagship programs (Anwar et al., 2020; Bradley, 2020). In short, training provides benefits in improving knowledge, skills, and abilities (K. Jehanzeb, 2013). In contrast, online training also has disadvantages. Based on preliminary studies conducted by the researcher in the field, online training is less effective, especially in the early days of utilizing online facilities for educational activities during the Covid-19 pandemic. Adaptation of all components of education to online facilities requires time and process. The problems found by researchers in the implementation of online training are that internet connection is difficult because most participants have not used good internet facilities such as wifi from Telkomsel, learning chat models in certain application facilities are not optimal, internet quota is running out, the ability of participants to access the learning management system varies, not all the participants and facilitators utilize a variety of features to maximize learning (I. Dhull, 2017; Ro'fah et al., 2020). The problem is increasing because schools have not prepared participants to understand and operate online facilities properly. The training seemed to be carried out suddenly without any careful planning. This problem has an impact on the quality of the training implementation.

Distance learning constraints include the availability of learning media (mobile phones, computers, or laptops), lack of mastery of Science and Technology, cost problems for purchasing internet packages (quota), time constraints, communication and socialization barriers between students, teachers, and parents, and the constraints of working hours that become unlimited for teachers because they have to communicate intensely and coordinate with parents, other teachers, and school principals (Bervell \& Arkorful, 2020; Costa et al., 2020; Selvaraj et al., 2021). The show that online learning is less effective in realizing the principles of complete learning, the interactions that occur between teachers and students are not optimal (different from conventional learning), the improvement in character values is not optimal, motivation, and the accuracy of the evaluation of the ability of students to understand the material is also not optimal (Waruwu, 2020).

The gap that between previous studies that are relevant to the results of preliminary studies conducted by researcher shows that there are problems in the implementation of online training. The success of online training is largely determined by the readiness of the required technology such as hardware, software, and networking, the readiness of human resources to master information technology, organizational readiness through leadership and policies and the quality of learning materials (Suprapto, 2019). The objective of this study is to analyze the effectiveness of the online model-based training program for prospective principals. The success rate of the training is measured using the Kirkpatrick evaluation model which includes 
4 (four) levels, they are 1) reaction; 2) learning; 3) behavior; 4) results (Calvo et al., 2019; Maudsley \& Taylor, 2020). Level 1 relates to the reactions, perceptions, and attitudes of participants after attending the training. At this level, participants are given a questionnaire to get feedback from participants about their feelings during the training (Bari et al., 2021). Level 2 is the learning level, referring to the learning of the trainees' professional knowledge or skills (Liao \& Hsu, 2019).

The level of participants' understanding of the material provided. The level of participants' understanding and mastery of knowledge, skills, and attitude values was obtained through pretest and posttest. Level 3 deals with changing participants' behavior by monitoring actual behavior in the workplace. Evaluation at this level is made using monitoring participants in the workplace to what extent they apply training materials, share knowledge with colleagues, change positive attitudes, improve performance. The last level, namely level 4 results This level refers to efforts to evaluate the extent to which training has an impact on improving performance, improving participant performance, and achieving results (Mahmoodi et al., 2019). The purpose of this research is the online mode-based education and training program for principals using the Kirkpatrick evaluation model. The results of this study are expected to have an impact on improving the quality of online training services.

\section{METHODS}

The type of research used was a mixed method. Quantitative data were analyzed with a qualitative analysis. The researcher used the mixed method because this method can reveal and explain the research results comprehensively. The subject of this research was the teacher. These teachers were prepared to carry out their mandate as school principals in the future. Then they were given additional duties as deputy principals in the field of curriculum and student affairs. This additional task was a form of regeneration at the school leadership level. The number of online training participants was 12 people from 4 (four) levels of Kindergarten, Elementary, Middle, and High School. Researchers used data collection methods in the form of questionnaires, interviews, observations, and documentation studies. In this study, the questionnaire is a list of written questions used to obtain information from the trainees about their impressions of the implementation of the training.

The purpose of the questionnaire is to obtain data in the form of the level of participant satisfaction with the implementation of online model-based training. The instrument used was a closed questionnaire with a Likert scale of 1 to 5 using the google form. Questionnaires were distributed to 12 training participants to be responded to according to their experiences during the training. The measured reaction aspects included (1) the skills and abilities of the education and training teachers; (2) management of online facilities (zoom meeting, whatsapp group, google meet) used; (3) time management; (4) the suitability of the media with the material; (5) the suitability of the training materials and objectives (6) the suitability of the exercises/tasks with the materials/topics (7) participants were given case studies or examples in school management. Aspects of behavioral change that were measured included (1) improved motivation at work; (2) improved knowledge, skills, and changing attitudes; (3) improvement of performance/competence in each work unit (behavior evaluation); (4) the application of materials in school management.

The purpose of interview data is to find out in-depth information about the learning outcomes of the trainees, which include absorption, pretest and posttest information, skills and attitudes improvement, and information on the impact of training on school organizations. The researcher conducted interviews with facilitators, principals, teachers, and participants. The observations made were active participation observations in which the researcher was involved in the activities under study. Researchers observed the planning, implementation, evaluation, 
and follow-up of training. The documentation was in the form of vision and mission, photos, recordings, excellent programs in the fields of managerial, supervision, and entrepreneurship. Data analysis to determine the effectiveness of this online training was using Kirkpatrick's four-level evaluation model stages which include Reaction Evaluation, Learning Evaluation, Behavior Evaluation, and Result Evaluation. These four levels of evaluation were used to measure the level of success of the training implementation at each stage.

\section{RESULTS AND DISCUSSION}

\section{Result}

The implementation of the training for prospective principals is considered successful if the participants are satisfied with the abilities of the education and training teachers, the attitude of the committee, training facilities, time management, media, materials, exercises and assignments, and case study examples. The following is the result of participants' reactions to the implementation of the training as shown in table 1.

Table 1. Reactions of Candidates for Principal Training Participants

\begin{tabular}{|c|c|c|c|}
\hline No & Indicator & $(\%)$ & Criteria \\
\hline 1 & Skills and abilities of education and training teachers & $84 \%$ & Good \\
\hline 2 & $\begin{array}{l}\text { Management of online facilities (Zoom Meeting, Group } \\
\text { WA, Google Meet) used }\end{array}$ & $82 \%$ & Good \\
\hline 3 & Time management & $80 \%$ & Good \\
\hline 4 & The suitability of the media with the material & $90 \%$ & Excellent \\
\hline 5 & Suitability of training materials and objectives & $88 \%$ & Excellent \\
\hline 6 & $\begin{array}{l}\text { The suitability of the exercise/task with the } \\
\text { material/topic }\end{array}$ & $88 \%$ & Excellent \\
\hline 7 & $\begin{array}{l}\text { Participants are given case studies or examples in school } \\
\text { management }\end{array}$ & $84 \%$ & Good \\
\hline & Average & $85.14 \%$ & Good \\
\hline
\end{tabular}

The description of the prospective principal's satisfaction with the implementation of the training can be seen in table 1 . In the table, the learning media, materials, and training tasks received responses in the excellent category from the participants. Meanwhile, the education and training teachers, online facilities, time management, and examples of case studies of learning implementation received good responses from the participants. Overall, the participants' reactions to the implementation of the training received a satisfactory response from participants. The results of this study support the opinion of Sahni that the evaluation of the reaction of the training program lies on the participants' satisfaction with training aspects such as the training atmosphere, training components (materials, curriculum, facilities), training benefits and the quality of instructors so that it has an impact on participant satisfaction (Sahni, 2020). Thus, the level of reaction in this training can measure the level of participant satisfaction where participants are satisfied toward the online training conducted by the master of education administration study program.

Then the results of the study found that it is necessary to improve the management of online facilities that are more professional, and the management of training time according to schedule. Both aspects get a lower level of satisfaction than other aspects. Online facilities are managed more professionally through the preparation of admin staff, the introduction of online facilities such as learning management systems, Zoom meetings, Google Meet, and Whatsapp groups, assistance for participant internet costs, internet network access for participants 
(Anugrahana, 2020; Handarini, Oktafia \& Wulandari, 2020; Lorenza \& Carter, 2021; Mahnun, 2018; Mishra et al., 2020; Muthuprasad et al., 2021a; Qazi et al., 2020; Rafique et al., 2021).

The objective of learning evaluation is to measure the extent to which participants understand the training material. At this stage the participants' absorption of the material will be seen, their mastery of knowledge, skills, and attitudes. To measure the participants' understanding of learning, the researcher gives a pretest and posttest. Based on the results of data analysis, $45 \%$ of participants scored in the excellent category, while $55 \%$ scored in the good category. Overall, participants experienced an increase in knowledge after participating in the training of prospective principals. Assessment of skills (performance) is an assessment of the ability of participants in completing tasks. The aspects assessed are problem-solving, systematic performance reports, and presentations. Each facilitator provides an assessment of the participants' performance results. The final result of the skill score (performance) is taken from the average of the overall scores of each facilitator. Based on the results of data analysis, shown that $10 \%$ of participants improve their skills in the excellent category, while $90 \%$ of participants improve their skills in the good category. Overall, the participants had a satisfactory improvement in their skills after participating in the training for prospective principals. Assessment of attitudes towards participants is carried out by setting two indicators, they are independent attitudes which include creative/innovative, firm, courageous opinion; and mutual cooperation, which includes active discussion, cooperation, consensus, solidarity. Attitude assessment is carried out on participants when participating in all training carried out in the On and In stages. The final result of the achievement of the participant's attitude score. Based on the results of data analysis, $36 \%$ of the participants received an attitude score in the excellent category, while $64 \%$ obtained an attitude score in the good category. Overall, the participants' attitude scores are scored in the satisfactory category.

\section{Discussion}

The results of this study show an increase in the knowledge, skills, and attitudes of participants after attending the training. These results have similarities to research show that training and workshops have a significant effect on increasing participants' knowledge (Smith et al., 2021). Training encourages the changes to the knowledge improvement, skills, and attitudes significantly. The results of this study also have similarities with research, that there is a change in knowledge that is better than before and after participating in the training (Kurniawati, R \& Hariwibowo, 2014). The results of training at the learning level encourage the ability of participants to get what is expected from the training program (Deodhar, M. and Powdwal, 2017). The training encourages participants to experience a learning process that ultimately has an impact on increasing knowledge.

Evaluation of the learning level based on the results of this study shows an increase in the knowledge, skills, and attitudes of participants after attending the training. This is in line with the Kirkpatrick \& Kirkpatrick learning level evaluation model that the learning level aims to know the success level of knowledge, skills, and attitudes which is obtained from the training program (Jain et al., 2021). Thus, online training has a significant effect on increasing the knowledge, skills, and attitudes of principal training participants. The research findings also indicate the need for improvement in the skills aspect. Based on the evaluation results of the level of achievement, most of the participants are in a good category (90\%). This level of achievement needs to be improved so that more and more participants advance to the category at the level of achievement at the excellent level. The strategies used are improving participants' motivation, improving participants' understanding of the material and tasks, mentoring and supervising facilitators (Buil et al., 2019; Carrascoa et al., 2020; Händel et al., 2020; Mclean et al., 2019; Nurhayati, 2018; Puspayanti, 2018).

Behavior change evaluation is conducted to determine the extent to which the participants' behavior had changed after attending training in their respective workplaces. 
Evaluation of changes in participant behavior is obtained through the school community such as school principals, teachers, and staff. Based on the results of data analysis, the changes in participant behavior can be seen in the improvement of motivation, knowledge, skills, changing attitudes, improving competence, the evaluation scores with a good category score, while the application of the material in school management obtains an excellent category score. Changes in behavior appear in the ability to transfer knowledge from the training learning environment to the workplace (Shen et al., 2017). The findings of this study indicate the success of changing the behavior of trainees in the workplace. These results have similarities with research that training has a positive influence on improving the competence and performance of trainees in the workplace (Nurjanah, 2019). The training program has a positive impact on changing participants' behavior in the work environment (Richard et al., 2019). The difference in previous research is that researcher finds an increase in workplace motivation in line with the increase in competence and performance expressed by previous researchers.

The research findings are an improvement in motivation at work after attending training. This aspect receives an assessment with a lower category than other aspects. Improving motivation at work is very important (Kurniasari, 2018; Lin et al., 2018). Consistent training can improve motivation (Darmawan et al., 2017; Firmansyah \& Aima, 2020; Suryaningsih \& AzhariRahim, 2019). School leaders have the task of monitoring so that the motivation of training participants has improved. The purpose of the result evaluation level is to find out the extent to which training has an impact on the development of organizational performance. Based on the results of interviews and field observations, the researcher finds that training had a significant impact on improving school quality. Prospective principals can improve the quality of schools through the ability to make school development plans and their implementation, changes in learning innovations, students' academic scores have improved from the previous semester, extracurricular activities are active again, the supervision of teaching staff is regularly scheduled, school promotion through online to the wider community getting massive. Training participants can be an inspiration for school development and they are ready to carry out their duties as school leaders in the future.

The results of the evaluation are considered to be successful if the desired results including bringing the changes to the organization, for example, there is the development of initiative and participation in the organization (E. Antoñanzas-Baztan et al, 2020; PeralboUzquiano et al., 2020). The findings of this study indicate the impact of training on school organizations such as increasing learning innovation, increasing students' academic scores, reactive extracurricular activities, school promotions, and so on. The resulting level does have an impact on organizational change both in the short and long term, but the implementation of change is hampered by funds and other funding sources (Abbas \& Sagsan, 2020; Alamsyahril, 2020; Fernández-García et al., 2021). The resulting level shows that training has an impact on the ability of participants to realize organizational targets. The productivity of the trainees is increasing. The result of the training program is to improve quality, cost, volume/production, efficiency, compliance, employee satisfaction, security, customer/market response, and customer satisfaction/consumer (Jones et al., 2018; Praslova, 2010). Thus, online-based training of principals candidate has an impact on increasing the productivity, satisfaction, and motivation of trainees.

\section{CONCLUSION}

The online mode-based training program for prospective principals is at a good level. The level of effectiveness of the training program at each level indicates that the level of reaction of participants to the implementation of online training is at good level; At the learning level, it shows that the improvement in knowledge, skills, and attitudes of participants after 
attending the training is at a good level; At the behavioral level, it shows that changes in the behavior of participants at work are at a good level; The result is at a good level.

\section{REFERENCES}

Abbas, J., \& Sagsan, M. (2020). Identification of key employability attributes and evaluation of university graduates' performance: Instrument development and validation. Higher Education, Skills and Work-Based Learning, 10(3), 449-466. https://doi.org/10.1108/heswbl-06-2019-0075.

Alamsyahril. (2020). Model Kirkpatrick Dalam Evaluasi Program Pelatihan Kepemimpinan Tingkat IV. Cendekia Niaga, 4(1), 35-43. https://doi.org/10.52391/jen.v4i1.490.

Albashtawi, A. H., \& Al Bataineh, K. B. (2020). The effectiveness of google classroom among EFL students in Jordan: An innovative teaching and learning online platform. International Journal of Emerging Technologies in Learning, 15(11), 78-88. https://doi.org/10.3991/ijet.v15i11.12865.

Andel, S. A., de Vreede, T., Spector, P. E., Padmanabhan, B., Singh, V. K., \& Vreede, G. J. de. (2020). Do social features help in video-centric online learning platforms? A social presence perspective. Computers in Human Behavior, 113(April), 106505. https://doi.org/10.1016/j.chb.2020.106505.

Anugrahana, A. (2020). Hambatan, Solusi dan Harapan : Pembelajaran Daring Selama Masa Pandemi Covid-19 Oleh Guru Sekolah Dasar. Scholaria: Jurnal Pendidikan Dan Kebudayaan, 10(3), 282-289. https://doi.org/10.24246/j.js.2020.v10.i3.p282-289.

Anwar, Y., Selamet, A., Huzaifah, S., \& Madang, K. (2020). Training in developing higherorder thinking based online test instrument for biology teachers in Sekayu City. Journal of Community Service and Empowerment, 1(3), 150-155. https://doi.org/10.22219/jcse.v1i3.12241.

Bari, S., Incorvia, J., Iverson, K. R., Bekele, A., Garringer, K., Ahearn, O., Drown, L., Emiru, A. A., Burssa, D., Workineh, S., Sheferaw, E. D., Meara, J. G., \& Beyene, A. (2021). Surgical data strengthening in Ethiopia: results of a Kirkpatrick framework evaluation of a data quality intervention. Global Health Action, 14(1). https://doi.org/10.1080/16549716.2020.1855808.

Bervell, B., \& Arkorful, V. (2020). LMS-Enabled Blended Learning Utilization in Distance Tertiary Education: Establishing the Relationships Among Facilitating Conditions, Voluntariness of Use and Use Behaviour. International Journal of Educational Technology in Higher Education, 17(1), 6. https://doi.org/10.1186/s41239-020-01839.

Bradley, V. M. (2020). Learning Management System (LMS) Use with Online Instruction. International Journal of Technology in Education, 4(1), 68. https://doi.org/10.46328/ijte.36.

Buil, I., Catalán, S., \& Martínez, E. (2019). The International Journal of Encouraging intrinsic motivation in management training: The use of business simulation games. The International Journal of Management Education, 17(2), 162-171. https://doi.org/10.1016/j.ijme.2019.02.002.

Calvo, S., Morales, A., \& Wade, J. (2019). The use of MOOCs in social enterprise education: an evaluation of a North-South collaborative FutureLearn program. Journal of Small Business and Entrepreneurship, 31(3), 201-223. https://doi.org/10.1080/08276331.2018.1453241.

Carrascoa, C. J. G., Rodríguez-Medinab, J., Martíneza, P. M., \& González, V. B. A. (2020). Effects of a teacher training program on the motivation and satisfaction of history secondary students. Revista de Psicodidáctica, 30(20), 1-7. https://doi.org/10.1016/j.psicoe.2020.08.001. 
Chen, E., \& Li, Z. (2011). On the application of multimedia technology in foreign language teaching and learning in China's colleges: Challenges, problems and implications. 2011 International Conference on Multimedia Technology, ICMT 2011, 595-597. https://doi.org/10.1109/ICMT.2011.6001903.

Choi, J. J., Robb, C. A., Mifli, M., \& Zainuddin, Z. (2021). University students' perception to online class delivery methods during the COVID-19 pandemic: A focus on hospitality education in Korea and Malaysia. Journal of Hospitality, Leisure, Sport and Tourism Education, 29(August), 100336. https://doi.org/10.1016/j.jhlste.2021.100336.

Costa, R. D., Souza, G. F., Valentim, R. A. M., \& Castro, T. B. (2020). The theory of learning styles applied to distance learning. Cognitive Systems Research, 64. https://doi.org/10.1016/j.cogsys.2020.08.004.

Darmawan, Y. Y., Supartha, W. G., \& Rahyuda, A. G. (2017). Pengaruh Pelatihan terhadap Motivasi Kerja dan Kinerja di Prama Sanur Beach-Bali. E-Jurnal Ekonomi Dan Bisnis Universitas Udayana, 3(6),

1265-1290. https://ojs.unud.ac.id/index.php/EEB/article/view/24219.

Deodhar, M. and Powdwal, S. (2017). Impact of Continuing Education Programs (CEPs) on LIS Professionals in Academic Libraries in Mumbai, India. Library Management, 38(2/3), 117-130. https://doi.org/10.1108/LM-07-2016-0051.

Dhawan, S. (2020). Online Learning: A Panacea in the Time of COVID-19 Crisis. Journal of Educational Technology Systems, 49(1), 5-22. https://doi.org/10.1177/0047239520934018.

E. Antoñanzas-Baztan et al. (2020). Design, Implementation and Evaluation of An Education Course to Promote Professional Self-Efficacy for Breastfeeding Care. Nurse Education in Practice, 45:102799. https://doi.org/10.1016/j.nepr.2020.102799.

Fernández-García, D., Giménez-Espert, M. del C., Hernández, P. C., \& Prado-Gascó, V. J. (2021). Do organizational variables influence satisfaction with nursing student practices? Studies in Educational Evaluation, 71. https://doi.org/10.1016/j.stueduc.2021.101068.

Firmansyah, A., \& Aima, H. (2020). Pengaruh pelatihan, kompensasi, dan motivasi kerja terhadap kinerja karyawan. Journal FEB Unmul: Kinerja, 17(2), 172-185. http://dx.doi.org/10.29264/jkin.v17i2.7050.

Guswara, A. M. (2020). The Contribution of Google Classroom Application and Motivation to The Learning Outcomes of Web Programming. Educational Technology, 4(4), 1-9. https://doi.org/10.23887/jet.v4i4.29896.

Haddock, L., Cannon, K., \& Grey, E. (2020). A Comparative Analysis of Traditional and Online Counselor Training Program Delivery and Instruction. The Professional Counselor, 10(1), 92-105. https://doi.org/10.15241/lh.10.1.92.

Handarini, Oktafia, I., \& Wulandari, S. S. (2020). Pembelajaran Daring Sebagai Upaya Study From Home (SFH) Selama Pandemi Covid-19. Jurnal Pendidikan Administrasi Perkantoran, 8(3). https://jurnal.unesa.ac.id/index.php/jpap/article/view/8503.

Händel, M., Harder, B., \& Dresel, M. (2020). Enhanced monitoring accuracy and test performance : Incremental effects of judgment training over and above repeated testing. Learning and Instruction, 65(1), 1-9. https://doi.org/10.1016/j.learninstruc.2019.101245.

Husain, B., Idi, Y. N., \& Basri, M. (2021). Teachers' Perceptions on Adopting E-Learning During Covid-19 Outbreaks; Advantages, Disadvantages, Suggestions. Jurnal Tarbiyah, 27(2), 41-57. https://doi.org/10.30829/tar.v27i2.738.

I. Dhull, M. S. (2017). Online Learning. International Education \& Research Journal [IERJ], 3(8), 32-34. https://doi.org/10.1007/978-3-030-33120-7_6.

Jain, G., Sharma, N., \& Shrivastava, A. (2021). Enhancing training effectiveness for 
organizations through blockchain-enabled training effectiveness measurement (BETEM). Journal of Organizational Change Management, 34(2), 439-461. https://doi.org/10.1108/JOCM-10-2020-0303.

Jones, C., Fraser, J., \& Randall, S. (2018). The evaluation of a home-based paediatric nursing service: concept and design development using the Kirkpatrick model. Journal of Research in Nursing, 23(6), 492-501. https://doi.org/10.1177/1744987118786019.

K. Jehanzeb, N. A. B. (2013). Training and Development Program and its Benefits to Employee and Organization: A Conceptual Study. European Journal of Business and Management, 5(2), 243-252. https://doi.org/10.1109/APEC.2016.7467900.

König, J., Jäger-Biela, D. J., \& Glutsch, N. (2020). Adapting to online teaching during COVID19 school closure: teacher education and teacher competence effects among early career teachers in Germany. European Journal of Teacher Education, 43(4), 608-622. https://doi.org/10.1080/02619768.2020.1809650.

Kurniasari, R. (2018). Pemberian Motivasi serta Dampaknya Terhadap Kinerja Karyawan Pada Perusahaan Telekomunikasi Jakarta. Widya Cipta, 2(1), 32-39. https://doi.org/10.31294/widyacipta.v2i1.2551.

Kurniawati, R \& Hariwibowo, P. (2014). Evaluasi Program Pelatihan Product Knowledge Departemen Marketing Delta Pada PT Phapros Tbk Semarang. Admisi Dan Bisnis, 15(1), 11-22. https://doi.org/10.32497/ab.v15i1.1010.

Lage-Cala, S., Folgueras-Díaza, M. B., Alonso-Hidalgoa, M., García-Menéndezb, D., \& Fernández-Garcíab, F. J. (2020). Investigation of the effectiveness of online learning tools for energy performance certificates preparation. Energy Reports, 6, 609-614. https://doi.org/10.1016/j.egyr.2019.09.034.

Liao, S.-C., \& Hsu, S.-Y. (2019). Evaluating A Continuing Medical Education Program: New World Kirkpatrick Model Approach. International Journal of Management, Economics and Social Sciences, 8(4), 266-279. https://doi.org/10.32327/IJMESS.8.4.2019.17.

Lin, H.-H., Yen, W.-C., \& Wang, Y.-S. (2018). Investigating the effect of learning method and motivation on learning performance in a business simulation system context: An experimental study. Computers \& Education, 1-32. https://doi.org/10.1016/j.compedu.2018.08.008.

Lorenza, L., \& Carter, D. (2021). International Journal of Educational Research Open Emergency online teaching during COVID-19: A case study of Australian tertiary students in teacher education and creative arts. International Journal of Educational Research Open, 2-2(May), 100057. https://doi.org/10.1016/j.ijedro.2021.100057.

Mahmoodi, M., Rashtchi, M., \& Abbasian, G. R. (2019). Evaluation of in-service teacher training program in iran: Focus on the Kirkpatrick model. Education and Self Development, 14(4), 20-38. https://doi.org/10.26907/esd14.4.03.

Mahnun, N. (2018). Implementasi Pembelajaran Online dan Optimalisasi Pengelolaan Pembelajaran Berbasis Online di Perguruan Tinggi Islam dalam Mewujudkan World Class University. IJIEM: Kajian Teori Dan Hasil Penelitian Pendidikan, 1(1), 29-36. http://dx.doi.org/10.24014/ijiem.v1i1.5240.

Maudsley, G., \& Taylor, D. (2020). Analysing synthesis of evidence in a systematic review in health professions education: observations on struggling beyond Kirkpatrick. Medical Education Online, 25(1). https://doi.org/10.1080/10872981.2020.1731278.

Mclean, L., Taylor, M., \& Jimenez, M. (2019). Career choice motivations in teacher training as predictors of burnout and career optimism in the fi rst year of teaching. Teaching and Teacher Education, 85, 204-214. https://doi.org/10.1016/j.tate.2019.06.020.

Mishra, L., Gupta, T., \& Shree, A. (2020). Online teaching-learning in higher education during lockdown period of COVID-19 pandemic. International Journal of Educational Research Open, 1, 100012. https://doi.org/10.1016/j.ijedro.2020.100012. 
Muhyiddin. (2020). Covid-19, New Normal, dan Perencanaan Pembangunan di Indonesia. Jurnal Perencanaan Pembangunan: The Indonesian Journal of Development Planning, 4(2), 240-252. https://doi.org/10.36574/jpp.v4i2.118.

Mulyono, H., Suryoputro, G., \& Jamil, S. R. (2021). The application of WhatsApp to support online learning during the COVID-19 pandemic in Indonesia. Heliyon, 7(8), e07853. https://doi.org/10.1016/j.heliyon.2021.e07853.

Muthuprasad, T., Aiswarya, S., Aditya, K. S., \& Jha, G. K. (2021a). Social Sciences \& Humanities Open Students, perception and preference for online education in India during COVID -19 pandemic. Social Sciences \& Humanities Open, 3(1), 100101. https://doi.org/10.1016/j.ssaho.2020.100101.

Muthuprasad, T., Aiswarya, S., Aditya, K. S., \& Jha, G. K. (2021b). Students' perception and preference for online education in India during COVID -19 pandemic. Social Sciences \& Humanities Open, 3(1). https://doi.org/10.1016/j.ssaho.2020.100101.

Mutohhari, F., Sofyan, H., \& Nurtanto, M. (2021). Technological Competencies: A Study on the Acceptance of Digital Technology on Vocational Teachers in Indonesia. Proceedings of the 1st International Conference on Law, Social Science, Economics, and Education, ICLSSEE 2021, 1-11. https://doi.org/10.4108/eai.6-3-2021.2305971.

Nurhayati, Y. (2018). Penerapan Model Kirkpatrick untuk Evaluasi Program Diklat Teknis Subtantif Materi Perencanaan Pembelajaran Di Wilayah Kerja Provinsi Kepulauan Riau. Andragogi: Jurnal Diklat Teknis Pendidikan Dan Keagamaan, 6(2), 170-187. https://doi.org/10.36052/andragogi.v6i2.63.

Nurjanah, A. (2019). Evaluasi Diklat Peningkatan Kompetensi Penilaian Kinerja Guru (PKG) dan Pengembangan Keprofesionalan Berkelanjutan (PKB). EDUKASI: Jurnal Penelitian Pendidikan Agama Dan Keagamaan, 17(3), 284-299. https://doi.org/10.32729/edukasi.v17i3.615.

Peralbo-Uzquiano, M., Fernández-Abella, R., Durán-Bouza, M., José-Manuel CotosYáñezBrenlla-Blanco, J.-C., \& Brenlla-Blanco, J.-C. (2020). Evaluation of the effects of a virtual intervention programme on cognitive flexibility, inhibitory control and basic math skills in childhood education. Computers \& Education, 159. https://doi.org/10.1016/j.compedu.2020.104006.

Praslova, L. (2010). Adaptation of Kirkpatrick's four level model of training criteria to assessment of learning outcomes and program evaluation in Higher Education. Educational Assessment, Evaluation and Accountability, 22(3), 215-225. https://doi.org/10.1007/s11092-010-9098-7.

Puspayanti, A. (2018). Evaluasi pembelajaran diklat menggunakan model countenance stake. Andragogi Jurnal Diklat Teknis Pendidikan Dan Keagamaan, 4(1), 143-167. https://doi.org/10.36052/andragogi.v6i1.52.

Qazi, A., Naseer, K., Qazi, J., Alsalman, H., Naseem, U., Yang, S., Hardaker, G., \& Gumaei, A. (2020). Children and Youth Services Review Conventional to online education during COVID-19 pandemic: Do develop and underdeveloped nations cope alike. Children and Youth Services Review, 119(October), 105582. https://doi.org/10.1016/j.childyouth.2020.105582.

Rafique, G. M., Mahmood, K., Warraich, N. F., \& Rehman, S. U. (2021). Readiness for Online Learning during COVID-19 pandemic: A survey of Pakistani LIS students. The Journal of Academic Librarianship, 102346. https://doi.org/10.1016/j.acalib.2021.102346.

Ramkissoon, P., Belle, L. J., \& Bhurosy, T. (2020). Perceptions and experiences of students on the use of interactive online learning technologies in Mauritius. International Journal of Evaluation and Research in Education. https://doi.org/10.11591/ijere.v9i4.20692.

Richard, K., Noujaim, M., Thorndyke, L. E., \& Fischer, M. A. (2019). Preparing Medical 
Students to Be Physician Leaders: A Leadership Training Program for Students Designed and Led by Students. MedEdPORTAL: The Journal of Teaching and Learning Resources, 15, 10863. https://doi.org/10.15766/mep_2374-8265.10863.

Ro'fah et al. (2020). Is Online Learning Accessible During COVID-19 Pandemic ? Voices and Experiences of UIN Sunan Kalijaga Students with Disabilities. Nadwa: Jurnal Pendidikan Islam, 14(1), 1-38. https://doi.org/10.21580/nw.2020.14.1.5672.

Sahni, J. (2020). Managerial training effectiveness: An assessment through Kirkpatrick framework. TEM Journal, 9(3), 1227-1233. https://doi.org/10.18421/TEM93-51.

Selvaraj, A., Radhin, V., KA, N., Benson, N., \& Mathew, A. J. (2021). Effect of pandemic based online education on teaching and learning system. International Journal of Educational Development, 85(May), 102444. https://doi.org/10.1016/j.ijedudev.2021.102444.

Sert, N., \& Boynueğri, E. (2017). Digital technology use by the students and english teachers and self-directed language learning. World Journal on Educational Technology: Current Issues, 9(1), 24. https://doi.org/10.18844/wjet.v9i1.993.

Shen, N., Yufe, S., Saadatfard, O., Sockalingam, S., \& Wiljer, D. (2017). Rebooting kirkpatrick: Integrating information system theory into the evaluation of web-based continuing professional development interventions for interprofessional education. Journal of Continuing Education in the Health Professions, 37(2), 137-146. https://doi.org/10.1097/CEH.0000000000000154.

Shirish, A., Chandra, S., \& Srivastava, S. C. (2021). Switching to online learning during COVID-19: Theorizing the role of IT mindfulness and techno eustress for facilitating productivity and creativity in student learning. International Journal of Information Management, 61(January), 102394. https://doi.org/10.1016/j.ijinfomgt.2021.102394.

Smith, I. M., Bayliss, E., \& Mukoro, F. (2021). Capability building for large-scale transformational change: Learning from an evaluation of a national programme. $B M J$ Open Quality, 10(1), 1-9. https://doi.org/10.1136/bmjoq-2020-000980.

Srifuengfung, M., Thana-udom, K., Ratta-apha, W., Chulakadabba, S., Sanguanpanich, N., \& Viravan, N. (2021). Impact of the COVID-19 pandemic on older adults living in longterm care centers in Thailand, and risk factors for post-traumatic stress, depression, and anxiety. Journal of Affective Disorders, 295(August), 353-365. https://doi.org/10.1016/j.jad.2021.08.044.

Sujarwo, S., Sukmawati, S., Akhiruddin, A., Ridwan, R., \& Suharti Siradjuddin, S. S. (2020). An Analysis of University Students' Perspective On Online Learning in The Midst of Covid-19 Pandemic. Jurnal Pendidikan Dan Pengajaran, 53(2), 125. https://doi.org/10.23887/jpp.v53i2.24964.

Suprapto, A. (2019). Analisis dimensi kebutuhan pra implementasi e-learning untuk meningkatkan mutu layanan pendidikan kampus di era revolusi industri 4.0. Attarbiyah, 28, 81. https://doi.org/10.18326/tarbiyah.v28i0.81-97.

Supriyanto, A., Hartini, S., Irdasari, W. N., Miftahul, A., Oktapiana, S., \& Mumpuni, S. D. (2020). Teacher professional quality: Counselling services with technology in Pandemic Covid-19. Counsellia: Jurnal Bimbingan Dan Konseling, 10(2), 176. https://doi.org/10.25273/counsellia.v10i2.7768.

Suryaningsih, I., \& AzhariRahim, R. (2019). Efektivitas Pelatihan Efikasi Diri dalam Meningkatkan Motivasi Belajar Siswa Kelas X SMA Insan Cendekia Syeck Yusuf Kab. Gowa. Jurnal Ilmiah Pendidikan Matematika, 2(2), 85-91. https://ejournals.umma.ac.id/index.php/equals/article/view/401.

Tuma, F. (2021). The use of educational technology for interactive teaching in lectures. Annals of Medicine and Surgery 62, 231-235. https://doi.org/10.1016/j.amsu.2021.01.051.

Van Nuland, S., Mandzuk, D., Tucker Petrick, K., \& Cooper, T. (2020). COVID-19 and its 
effects on teacher education in Ontario: a complex adaptive systems perspective. Journal of Education for Teaching, 46(4), 442-451. https://doi.org/10.1080/02607476.2020.1803050.

Waruwu, M. (2020). Studi Evaluatif Implementasi Pembelajaran Daring Selama Pandemi Covid-19. Jurnal Administrasi Pendidikan, 27(2), 288-295. https://doi.org/10.17509/jap.v27i2.27081.

Yavuz, M., Çorbacioğlu, E., Başoğlu, A. N., Daim, T. U., \& Shaygan, A. (2021). Augmented reality technology adoption: Case of a mobile application in Turkey. Technology in Society, 66. https://doi.org/10.1016/j.techsoc.2021.101598. 